\title{
Estriol strongly inhibits DNCB-induced contact dermatitis: role of antigen-specific antibodies in pathogenesis
}

\author{
Elizabeth Yan Zhang ${ }^{1,+}$ and Bao-Ting Zhu ${ }^{1,2}$ \\ 'Department of Pharmacology, Toxicology and Therapeutics, School of Medicine, University of Kansas Medical \\ Center, Room 4061 of KLSIC Building, 2146 West 39th Street, Kansas City, Kansas 66160, USA \\ ${ }^{2}$ Department of Biology, South University of Science and Technology of China, Shenzhen, \\ Guangdong 518055, China \\ ${ }^{\dagger} \mathrm{E}$ Y Zhang is now at Division of Cell Biology, La Jolla Institute for Allergy and Immunology, La Jolla, California, USA
}

\begin{abstract}
The endogenous estrogens are important modulators of the immune system and its functions. However, their effects are rather complex and many aspects have not been studied. In this study, we used the 1-chloro-2,4-dinitrobenzene (DNCB)-induced contact dermatitis as a disease model and investigated the effect of estriol $\left(E_{3}\right)$, along with two other estrogens, $17 \beta$-estradiol and estrone, on the pathogenesis of contact hypersensitivity. A series of parameters, such as ear swelling, skin inflammation, antigen-specific immunoglobulins, and lymphocyte compositions in peripheral lymphoid organs, were evaluated in mice following development of contact dermatitis. We found that administration of all three estrogens elicited strong inhibition of DNCB-induced dermatitis, while $E_{3}$ exerted the strongest suppressive effect. Administration of $E_{3}$ alleviated dermatitis, and this effect was accompanied by decreases in serum DNCB-specific immunoglobulins, such as $\lg A, \lg G 1, \lg G 2 a$, and $\lg G 2 b$. Besides, treatment with $E_{3}$ reduced $B$ cell population, especially lgG-producing cells in the peripheral lymphoid organs following the induction of dermatitis. These observations consistently suggest that the antibody $(\mathrm{Ab})$-mediated humoral immune reactions play a critical role in the pathogenesis of DNCB-induced contact dermatitis. The results from this study demonstrate, for the first time, that estrogen administration has a strong suppressive effect on the pathogenesis of contact dermatitis. These findings offer important insights concerning the pathogenic role of antigen-specific Abs in contact dermatitis and the treatment of chemical-induced, Ab-mediated skin hypersensitivity reactions in humans.
\end{abstract}
Key Words
- estrogens
- estriol
- estrone
- 17 $\beta$-estradiol
- DNCB-induced contact dermatitis
- delayed type hypersensitivity
- skin hypersensitivity
- antigen-specific antibody
- humoral immune responses

Endocrine Connections (2014) 3, 161-172

\section{Introduction}

Many earlier studies have shown that estrogens are important modulators of immune system functions. It was demonstrated that although physiological levels of estrogens are immunostimulatory, high or super-physiological levels of estrogens, such as those observed during human pregnancy, are immunosuppressive (1). For example, $17 \beta$-estradiol $\left(\mathrm{E}_{2}\right)$ and estriol $\left(\mathrm{E}_{3}\right)$ at suitable doses can inhibit the development of experimental autoimmune http://www.endocrineconnections.org DOI: 10.1530/EC-14-0080 (c) 2014 The authors Published by Bioscientifica Ltd

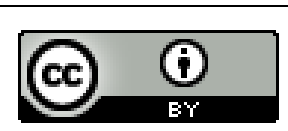

This work is licensed under a Creative Commons Attribution 3.0 Unported License. 
encephalomyelitis (EAE) $(2,3,4)$ and collagen-induced arthritis in murine models (3), and $\mathrm{E}_{2}$ can also suppress inflammatory response in castrated male mice (5). Besides, certain $\mathrm{E}_{2}$ derivatives were found to have a beneficial effect on inflammatory bowel disease in a murine model (6).

The hapten-induced contact dermatitis, also called contact hypersensitivity (CHS) or delayed type hypersensitivity (DTH), was initially considered as a predominant $\mathrm{T}$ cell-mediated immune response $(7,8,9,10,11,12)$. Lately, it was reported that B-1 cells or NK cells are also involved in the mediation of this immune response $(9,13$, $14,15)$. We have recently shown that $B$ cells and the formation of hapten-specific antibodies (Abs) play a critical role in the pathogenesis of hapten-induced CHS (16).

While a few earlier studies have suggested that $E_{2}$ can inhibit DTH reactions (17), there was only one earlier study published some 30 years ago that examined the effect of $\mathrm{E}_{3}$ on DTH reactions in mouse footpads against injected sheep red blood cells (SRBC) (18). In that study, however, a conclusion could not be reached because $\mathrm{E}_{3}$ was found to have a suppressive effect against a low dose of the SRBC antigen, whereas promoting the reaction when higher doses of the antigen were used. In this study, we sought to investigate the modulating effect of $\mathrm{E}_{3}$, an unique estrogen that is predominantly produced in large quantity during human pregnancy $(19,20)$, on the allergic contact dermatitis induced by topical application of 1-chloro-2, 4-dinitrobenzene (DNCB), and its effect was compared with two other common estrogens, $\mathrm{E}_{2}$ and estrone $\left(\mathrm{E}_{1}\right)$.

\section{Materials and methods}

\section{Chemicals and reagents}

DNCB (99\% purity) was purchased from Acros Organics (Fair Lawn, NJ, USA). $E_{1}, E_{2}, E_{3}$, cholesterol, dexamethasone (Dex), Tween-20, albumin from chicken egg white (ovalbumin, OVA, 98\% purity), and 1,2-phenylenediamine (OPD, 99.5\% purity) were obtained from Sigma-Aldrich. Fluorochrome-conjugated Abs were purchased from BD Biosciences (San Jose, CA, USA), eBioscience (San Diego, CA, USA), or Biolegend (San Diego, CA, USA). Other reagents used in this study were obtained from Fisher Scientific (Pittsburgh, PA, USA).

\section{DNCB-induced contact dermatitis in mice}

Experimental protocols involving the use of live animals were approved by the Institutional Animal Care and Use Committees (IACUC) of the University of South Carolina (Columbia,
SC, USA) and the University of Kansas Medical Center (Kansas City, KS, USA). The 6- to 8-week-old male Balb/c mice with the average body weight of $18 \mathrm{~g}$ were obtained from Harlan Laboratories (Houston, TX, USA). After arrival, they were allowed to acclimatize for a week before used in experimentation. The animals were housed under controlled conditions of temperature $\left(22^{\circ} \mathrm{C}\right)$ and photoperiod $(12 \mathrm{~h}$ light: $12 \mathrm{~h}$ darkness cycle), and they were allowed free access to food and water throughout the experiment.

To induce contact dermatitis, the animals were first sensitized by painting $100 \mu \mathrm{l}$ of $2 \%$ DNCB in ethanol onto the shaved back skin twice with a 12-day interval. Five days later, $20 \mu \mathrm{l} \mathrm{DNCB}$ was painted on the left ear twice with a 60-min interval (Fig. 1A). Twenty-four hours later, the ear swelling was evaluated by measuring the differences in the thickness (with an engineer's micrometer) and the weight of a small round piece cut out by using a sharp clamp between the right and left ears. The control animals were painted with ethanol alone on their shaved backs and left ears. There were six to eight mice in each group.

\section{Administration of estrogens and Dex}

Ten milligrams of $\mathrm{E}_{1}, \mathrm{E}_{2}$, or $\mathrm{E}_{3}$ and $15 \mathrm{mg}$ cholesterol were mixed thoroughly and then manually pressed by the same person by applying consistent pressure using a Pellet Presser (Parr Instrument Company, Moline, IL, USA) to produce pellet with a total weight of $25 \mathrm{mg}$. The vehicle pellet (containing only $25 \mathrm{mg}$ cholesterol) was prepared in the same manner. Each pellet was implanted surgically under the back skin of each animal 16 days before the start of the DNCB treatment. The control animals received the pellets that contained $25 \mathrm{mg}$ cholesterol alone. One day before the DNCB treatment, each mouse in the Dex-treated group received an i.m. injection of Dex at $10 \mathrm{mg} / \mathrm{kg}$ b.w. once every 2 days until the end of the experiment when the animals were killed.

\section{Histopathological analysis}

The formalin-fixed, paraffin-embedded ear tissues were sectioned at $5-\mu \mathrm{M}$ thickness, and the sections were stained with hematoxylin and eosin $(\mathrm{H} / \mathrm{E})$. The pictures were taken using a light microscope at a $100 \times$ magnification.

\section{Weight index}

The mouse body weight was measured right before the animals were killed. The spleen and thymus were removed and weighted. The weight index refers to the weight of an organ (mg) divided by the total body weight ( $\mathrm{g}$ ).

This work is licensed under a Creative Commons Attribution 3.0 Unported License. 
A
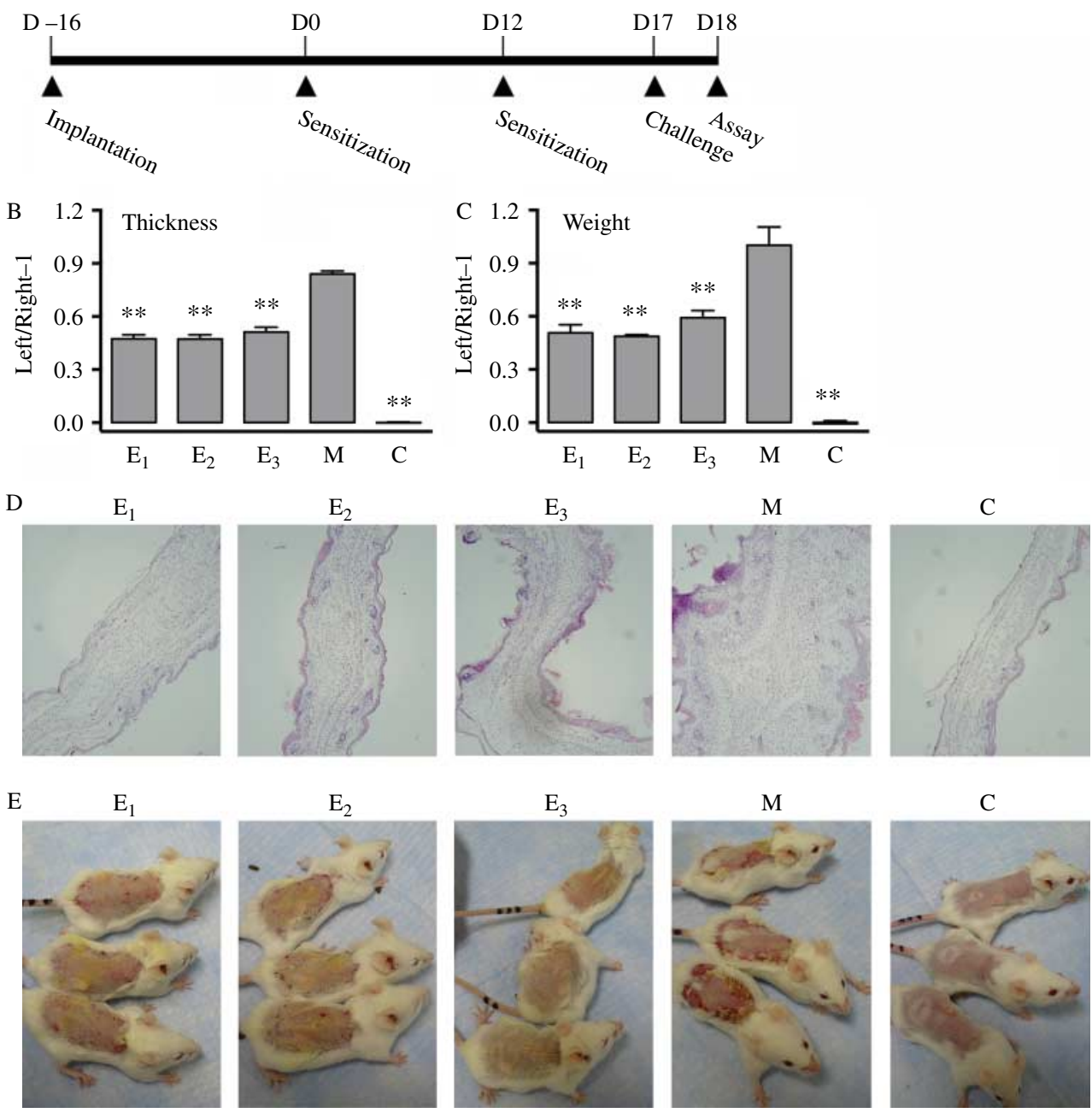

\section{Figure 1}

Administration of estrogen significantly inhibits DNCB-induced contact dermatitis. (A) The experimental schedule used in this study. Each mouse was implanted with a pellet containing an estrogen or vehicle under the back skin on day -16 , and sensitized by painting $100 \mu$ of $2 \%$ DNCB in ethanol or vehicle on the shaved back skin on day 0 and day 12 . The mouse was then challenged by painting $20 \mu \mathrm{l}$ of $2 \%$ DNCB in ethanol on the left ear twice with a 60-min interval on day 17, and assays were carried out the next day. ( $B$ and $C$ ) Ear swelling index was based on the increase in thickness (B) and weight (C) from the DNCB-challenged left ear to vehicle-challenged

\section{Flow cytometry analysis}

Immediately after the inguinal lymph nodes (LNs), spleens, and thymus were isolated, they were ground and the cells were strained to obtain the single cell suspensions. The cell quantity was determined by using a hematocytometer. After incubation with the $\mathrm{Ab}$ conjugated with fluorochrome followed by washing twice with FACS buffer (2\% FBS in PBS), the samples

\begin{tabular}{|lr}
\hline http://www.endocrineconnections.org & ๑ 2014 The authors \\
DOI: $10.1530 /$ EC-14-0080 & Published by Bioscientifica Ltd
\end{tabular}

right ear using the following formula: value (thickness or weight) of left ear/right ear-1. (D) Histological changes in $\mathrm{H} / \mathrm{E}$-stained tissue sections. (E) The severity of skin inflammation on the back of mice at 8 days after first sensitization with DNCB. It should be noted that in the data shown in this figure, mice labeled as group ' $E_{3}$ ' received $E_{3}+D N C B$; mice labeled as group ' $\mathrm{E}_{2}$ ' received $\mathrm{E}_{2}+\mathrm{DNCB}$; mice labeled as group ' $\mathrm{E}_{1}$ ' received $\mathrm{E}_{1}+\mathrm{DNCB}$; mice labeled as group ' $\mathrm{M}$ ' received a vehicle pellet+DNCB; and mice labeled as group ' $C$ ' received vehicles only. $n=6$ for each group. $* * P<0.01$ vs the group of mice treated with DNCB alone 'M'.

were fixed with $2 \%$ paraformaldehyde in PBS overnight and measured on the flow cytometer, and the data were analyzed using the Flowjo software (Tree Star, Inc., Ashland, OR, USA).

\section{Measurement of serum Ab levels}

The dinitrophenyl-OVA conjugate was prepared by stirring $1 \%$ OVA in the sodium borate buffer $(0.05 \mathrm{M}$,

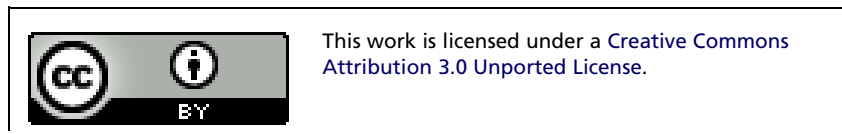


$\mathrm{pH} 9.4)$ at $4{ }^{\circ} \mathrm{C}$. DNCB powder $(0.01 \mathrm{~mol})$ was gradually added to the solution followed by dialysis against the sodium borate buffer. The solution was centrifuged at $300 \boldsymbol{g}$ for $5 \mathrm{~min}$. The supernatants were sequentially dialyzed against distilled water at $4{ }^{\circ} \mathrm{C}$. The conjugates were then lyophilized and stored at $-80^{\circ} \mathrm{C}$ until use. The measurement of DNCB-specific Abs and total Abs was carried out as previously reported (16).

\section{Statistical analysis}

Data are presented as mean \pm s.D. and were analyzed using a one-way ANOVA or two-way ANOVA and a multiple comparisons post hoc analysis (Dunnett's method) to test the difference between the DNCB treatment only group and the other groups.

\section{Results}

\section{Inhibition of DNCB-induced contact dermatitis by estrogens}

To test the role of estrogens $\left(\mathrm{E}_{3}, \mathrm{E}_{2}\right.$, and $\left.\mathrm{E}_{1}\right)$ on the pathogenesis of contact dermatitis, the animals received s.c. implantation of a $25 \mathrm{mg}$ pellet containing $10 \mathrm{mg} \mathrm{E}_{3}, \mathrm{E}_{2}$, or $\mathrm{E}_{1}$ to provide a sustained release of the estrogens. Sixteen days after pellet implantation, the animals were sensitized with DNCB and followed by a second sensitization 12 days later. DNCB challenge reaction was given 5 days after second sensitization and measurements were made $24 \mathrm{~h}$ later (Fig. 1A).

Treatment of animals with $\mathrm{E}_{3}, \mathrm{E}_{2}$, or $\mathrm{E}_{1}$ attenuated DNCB-induced ear swelling, based on changes in ear thickness and wet weight (Fig. 1B and C). Histopathological analysis showed that treatment with DNCB alone induced severe inflammatory infiltration, vascular congestion, and moderate edema in ear dermis (Fig. 1D). In comparison, skins of mice co-treated with an estrogen displayed only mild cellular infiltration and vasodilation without marked edema (Fig. 1D). After exposure to DNCB alone for 8 days, the animals began to develop strong skin hypersensitivity reactions in the treated areas (Fig. 1E). This observation is consistent with our earlier observations (16), i.e., dermatitis began to appear on sensitized back skin 8 days after initial exposure to DNCB, and the scar formation was usually very severe and would last for several days. However, the degree of skin inflammation in animals co-treated with $\mathrm{E}_{3}, \mathrm{E}_{2}$, or $\mathrm{E}_{1}$ was markedly reduced compared with animals treated with only DNCB. Notably, the degree of skin inflammation in $\mathrm{E}_{3}$-treated mice was least severe, and $\mathrm{E}_{3}$ alleviated the hypersensitivity reaction in the back skin to a level almost comparable with the animals treated with vehicle only (without DNCB) (Fig. 1E).

Effects of estrogens on body weight, organ weight index, and cell numbers in the lymphoid organs of mice that develop DNCB-induced contact dermatitis

To determine the toxicity of the chemical agents administered, change in the body weight during the experiment as well as the changes in spleen and thymus weight indices at the end of the experiment was measured. After the first sensitization with DNCB on the back skin, the animals exhibited a slight decrease $(<6 \%)$ in body weight compared with vehicle-treated animals. However, after implantation of an $\mathrm{E}_{3}$ pellet, the body weight of each mouse rapidly decreased. $\mathrm{E}_{3}$ caused a $12 \%$ body weight reduction in $4-5$ days. The body weight of $\mathrm{E}_{3}$-treated mice increased gradually afterwards. The average plasma concentrations of free $\mathrm{E}_{3} 5$ days after pellet implantation were found to be at $3.6 \mathrm{ng} / \mathrm{ml}(12.5 \mathrm{nM})$ (data not shown; referred in (21)). In comparison, treatment of animals with $\mathrm{E}_{1}$ or $\mathrm{E}_{2}$ produced smaller reductions in their body weight (Fig. 2A).

DNCB treatment did not alter spleen weight index significantly, but decreased thymus weight index by $\sim 40 \%$ compared with vehicle-treated animals. While the animals treated with $\mathrm{E}_{3}+\mathrm{DNCB}$ had a $30 \%$ reduction in their spleen weight index, animals treated with $\mathrm{E}_{2}$ or $\mathrm{E}_{1}+\mathrm{DNCB}$ did not have significant reduction in their spleen weight index (Fig. 2B). In the thymus, treatment of $\mathrm{E}_{3}+\mathrm{DNCB}$ drastically reduced its weight index by up to $80 \%$ compared with animals treated with DNCB alone, and this reduction was $\sim 90 \%$ compared with vehicle-treated mice. Co-administration of $\mathrm{E}_{2}$ or $\mathrm{E}_{1}+\mathrm{DNCB}$ also caused huge decrease in thymus weight index (Fig. 2B).

DNCB caused a small increase in the number of splenocytes. However, in mice treated with $\mathrm{DNCB}+$ an estrogen $\left(E_{3}, E_{2}\right.$, or $\left.E_{1}\right)$, the splenocyte numbers were significantly reduced compared with DNCB treatment alone, and these numbers were even lower than the animals treated with vehicle alone (Fig. 2C).

In the thymus, DNCB treatment reduced the thymocyte numbers by $\sim 40 \%$, which is consistent with the change in thymus weight (Fig. 2C). Addition of an estrogen $\left(\mathrm{E}_{3}, \mathrm{E}_{2}\right.$, or $\left.\mathrm{E}_{1}\right)$ to DNCB-treated mice further reduced thymocyte numbers to $\sim 15 \%$ of the numbers seen in animals treated with DNCB alone (Fig. 2C). It is evident

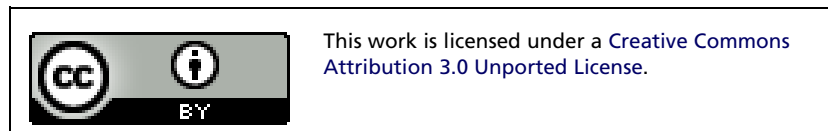




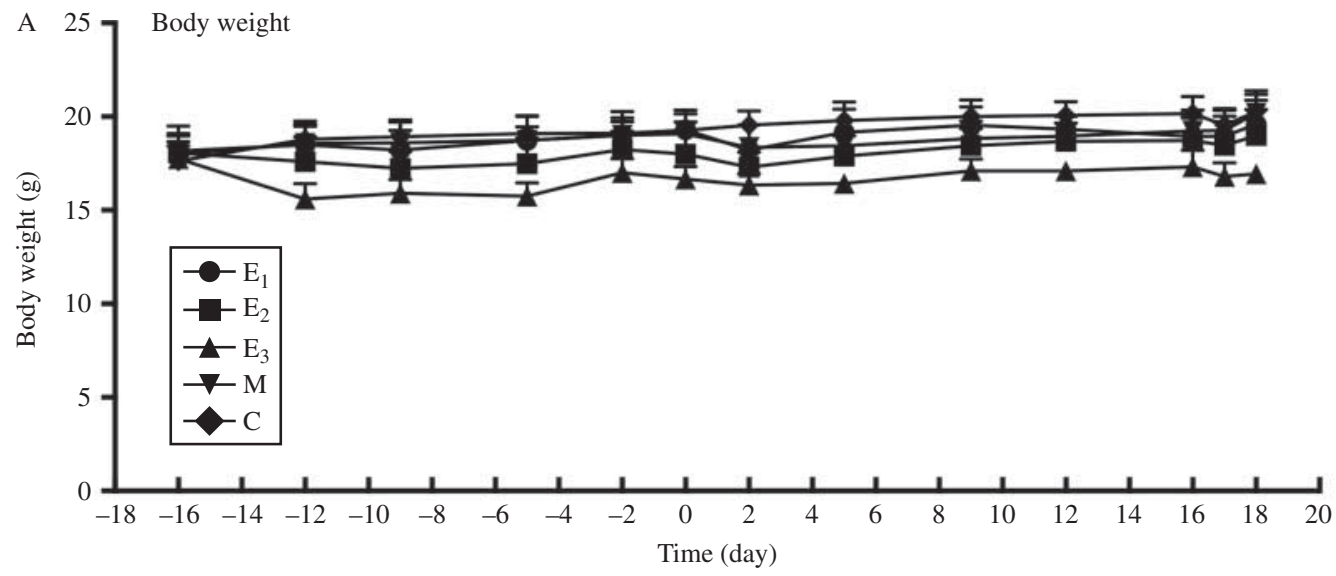

Implantation

Sensitization

Sensitization Challenge Assay
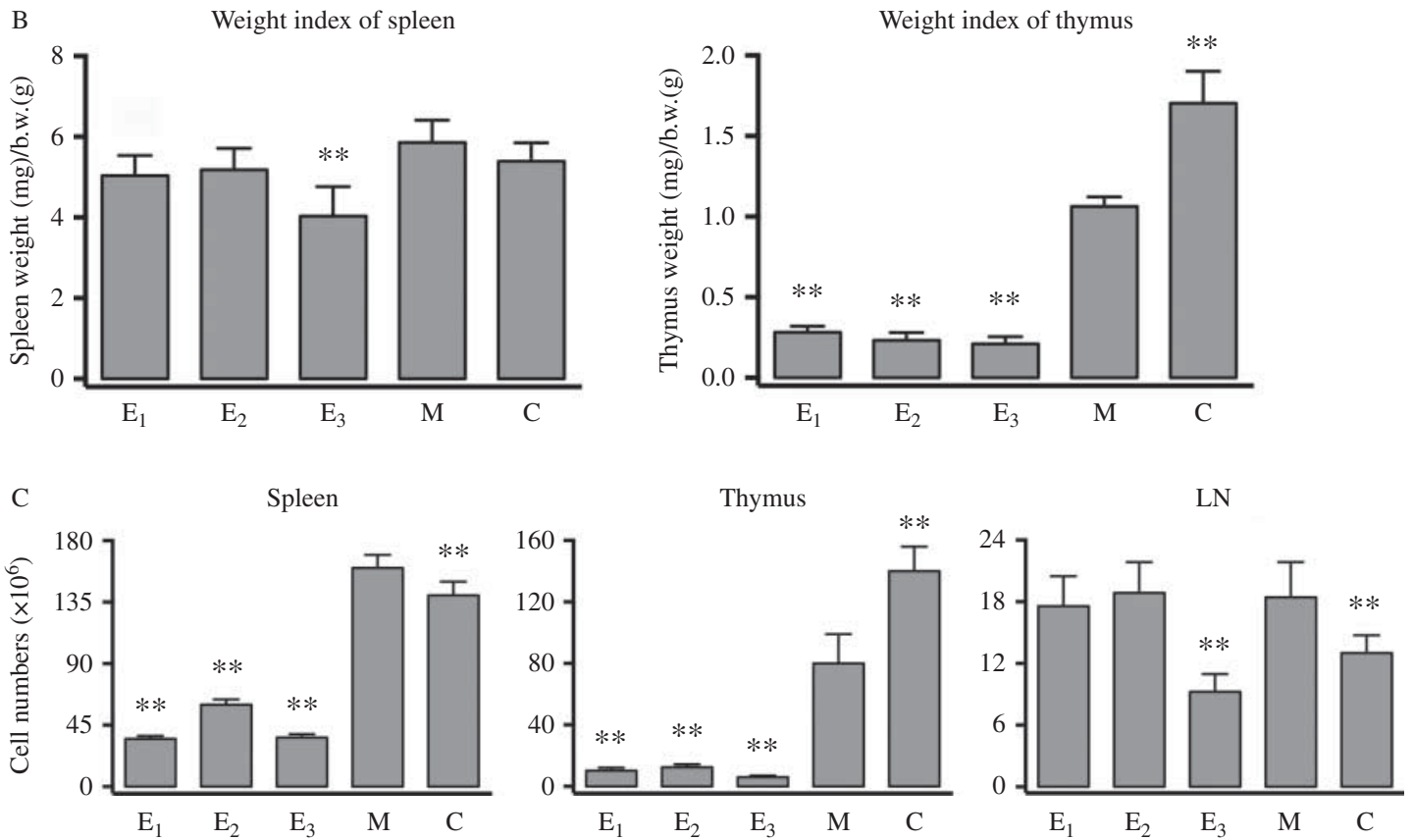

\section{Figure 2}

Effect of estrogen treatment on body weight, organ weight indices, and cell numbers in lymphoid organs from mice with DNCB-induced dermatitis. (A) The change in body weight during the experiment is shown. (B) On day 18 , the weight of different organs was measured. The organ weight indices (left panel: spleen; right panel: thymus) were calculated using this formula:

that among the three estrogens tested, $\mathrm{E}_{3}$ produced the strongest reduction in thymocyte population (Fig. 2C).

DNCB treatment increased the cell numbers in peripheral LNs by $\sim 40 \%$ over vehicle treatment. While mice receiving $\mathrm{E}_{1}$ or $\mathrm{E}_{2}$ in addition to $\mathrm{DNCB}$ did not alter LN cell numbers compared with DNCB alone, co-treatment with $\mathrm{E}_{3}$ reduced $\mathrm{LN}$ cell numbers by up to $50 \%$ compared with DNCB alone (Fig. 2C). organ weight $(\mathrm{mg}) / \mathrm{body}$ weight $(\mathrm{g})$. (C) On day 18, the cell numbers of lymphoid organs were determined by a hemocytometer (left panel: spleen; middle panel: thymus; right panel: peripheral lymph nodes). Refer to Fig. 1 for the meaning of the group labels. $n=6$ for each group. ${ }^{*} P<0.01$ vs the group of mice treated with DNCB alone ' $M$ '.

\section{Treatment with estrogens significantly suppressed the DNCB-specific Abs in mice that develop DNCB-induced contact dermatitis}

We previously reported that the antigen-specific Abs play an indispensable role in the development of antigeninduced CHS (16). Therefore, we investigated in this study whether the suppressive effect of estrogens on the

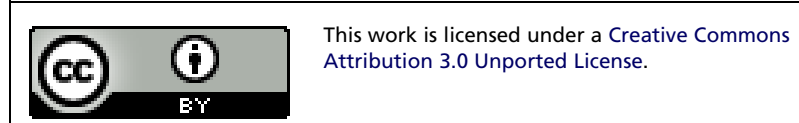


pathogenesis of DNCB-induced CHS is associated with the levels of DNCB-specific Abs. Because $\mathrm{E}_{3}$, among the three estrogens tested, has the strongest inhibition of CHS (Fig. 1E), we presented only the data regarding the modulating effect on DNCB-specific Abs. The suppression of DNCB-induced skin hypersensitivity by $\mathrm{E}_{3}$ (as presented in Fig. 1B, C, D, and E) was found to be accompanied by marked reductions ( $\geq 50 \%$ ) in DNCB-specific serum Abs (e.g., specific IgA, IgG, IgG1, IgG2a, and IgG2b) compared with animals treated with DNCB alone (Fig. 3A).

In contrast to the induction of DNCB-specific Abs, DNCB treatment did not significantly change the serum levels of total IgA, IgG2a, and IgG3, only slightly reduced the levels of total IgM, but increased the levels of total IgG, particularly IgG1 and IgG2b (Fig. 3B). The effects of $E_{3}$ on serum levels of total Abs were more complex. Treatment of $\mathrm{E}_{3}+\mathrm{DNCB}$ did not produce change in serum levels of total IgG1 as compared with the animals treated with DNCB alone, but it increased the serum levels of total IgA, IgG, IgG2a, IgG2b, IgG3, and IgM. It is of note that $\mathrm{E}_{3}$ treatment brought the total IgG3 and IgM levels nearly equal to the levels observed in vehicle-treated control animals (Fig. 3B).

\section{Effect of estrogens on the lymphocyte composition in peripheral lymphoid organs of mice with DNCB-induced contact dermatitis}

Contact dermatitis is usually treated by topical or systemic application of glucocorticoids, such as Dex $(11,22)$. We have reported earlier that administration of Dex inhibited DNCB-induced CHS by suppressing the production of DNCB-specific Abs (16). In this study, we found that $\mathrm{E}_{3}$ exerted a similar suppressive effect on DNCB-induced CHS, and this effect was accompanied by a significant decrease in the production of DNCB-specific Abs. Hence, we included Dex as a positive control for suppressing the pathological development of contact dermatitis in some of the additional analyses which sought to compare whether $\mathrm{E}_{3}$ exerts similar effects as Dex on peripheral lymphocyte depletion (23).

In splenocytes, DNCB treatment reduced the percentage of $\mathrm{T}$ cells (e.g., TCR $\alpha \beta^{+}, \mathrm{CD} 4^{+}$, and $\mathrm{CD} 8^{+}$cells) compared with the control animals (Fig. $4 \mathrm{~A}$ and $\mathrm{B}$ ), but the percentage of splenic B cells (e.g., B220 ${ }^{+}$and $\mathrm{IgG}^{+}$cells) were not similarly changed by the treatment (Fig. $4 \mathrm{C}$ and D). DNCB treatment did not have marked changes in the percentages of splenic macrophages $\left(\mathrm{F} 4 / 80^{+}\right)$or TCR $\gamma \delta^{+}$ cells (Fig. 4E and F) (16). Co-administration of $\mathrm{E}_{3}$ or Dex increased the percentage of splenic T cells $\left(\mathrm{TCR} \alpha \beta^{+}, \mathrm{CD} 4^{+}\right.$, and $\mathrm{CD}^{+}$cells) (Fig. 4A and B), but reduced the percentage of splenic B220 ${ }^{+}$and $\mathrm{IgG}^{+}$cells (Fig. 4C and D). While Dex had a stronger effect than $E_{3}$ in the induction of TCR $\alpha \beta^{+}$ cells and the suppression of $\mathrm{IgG}^{+}$cells, both of them increased the levels of $\mathrm{TCR} \gamma \delta^{+}$cells, with $\mathrm{E}_{3}$ having a stronger effect (Fig. 4A and D). In addition, $\mathrm{E}_{3}$ significantly increased the percentage of splenic macrophages whereas Dex did not show a similar effect (Fig. 4E and F).

In peripheral LNs, treatment with $\mathrm{DNCB}$ decreased the percentage of T cells (TCR $\alpha \beta^{+}$and $\mathrm{CD} 4^{+}$) (Fig. 5A and B), but increased the percentage of B cells $\left(\mathrm{B}_{2} 20^{+}\right.$and $\left.\mathrm{IgG}^{+}\right)$ (Fig. 5C and D). In general, DNCB treatment inhibited $\mathrm{T}$ cells, especially $\mathrm{T}_{\mathrm{H}}$ cells, but promoted the production of $\mathrm{B}$ cells in peripheral LNs. Compared with DNCB treatment alone, co-administration of $\mathrm{E}_{3}$ or Dex $+\mathrm{DNCB}$ decreased the percentage of $\mathrm{LN} \mathrm{T}$ cells $\left(\mathrm{TCR} \alpha \beta^{+}, \mathrm{CD} 4^{+}\right.$, and $\mathrm{CD} 8^{+}$ cells) (Fig. 5A and B), and also decreased the percentage of

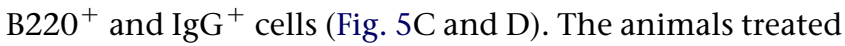
with Dex had the lowest percentage of $\mathrm{LN} \mathrm{B220}{ }^{+}$and $\mathrm{IgG}^{+}$cells, which was even lower than the vehicle group (Fig. 5C and D). Treatment of $\mathrm{E}_{3}$, but not Dex, increased the percentage of macrophage $\left(\mathrm{F} 4 / 80^{+}\right)$compared with the DNCB treatment alone (Fig. 5E). However, Dex, but not $\mathrm{E}_{3}$, increased the percentage of $\mathrm{TCR} \gamma \delta^{+}$cells (Fig. 5F). Therefore, $\mathrm{E}_{3}$ and Dex displayed rather different effects on lymphocyte composition in peripheral lymphoid organs of mice that developed DNCB-induced contact dermatitis.

The composition of thymocytes was found to be similar in mice treated with DNCB alone or vehicle alone (data not shown), thereby suggesting that the changes in thymocytes appear to be less important in the pathogenesis of DNCB-induced contact dermatitis.

\section{Discussion}

The results of our present study showed that the DNCBinduced contact dermatitis is associated with a strong inhibition of peripheral T cells (Figs 4A, B and 5A, B) and thymocytes number (Fig. 2C). Co-administration of $\mathrm{E}_{3}$ produced a further drastic inhibition of $\mathrm{LN} \mathrm{T}$ cells and thymocytes. This effect of $\mathrm{E}_{3}$ has led to the suggestion that its rescue mechanism in DNCB-induced contact dermatitis likely is not mediated through changes in T cells and their functions. By contrast, treatment of mice with DNCB increased the $\mathrm{B}$ cell composition in peripheral lymphoid organs (Figs 4D and 5C, D), accompanied by increases in DNCB-specific Abs (Fig. 3A). Co-treatment with $\mathrm{E}_{3}$ brought these parameters to the levels close to vehicle-treated animals. It was quite amazing to observe that administration of $\mathrm{E}_{3}, \mathrm{E}_{1}$, or $\mathrm{E}_{2}$, strongly alleviates DNCB-induced

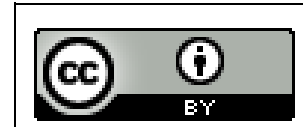

This work is licensed under a Creative Commons Attribution 3.0 Unported License. 
A DNCB-specific Abs
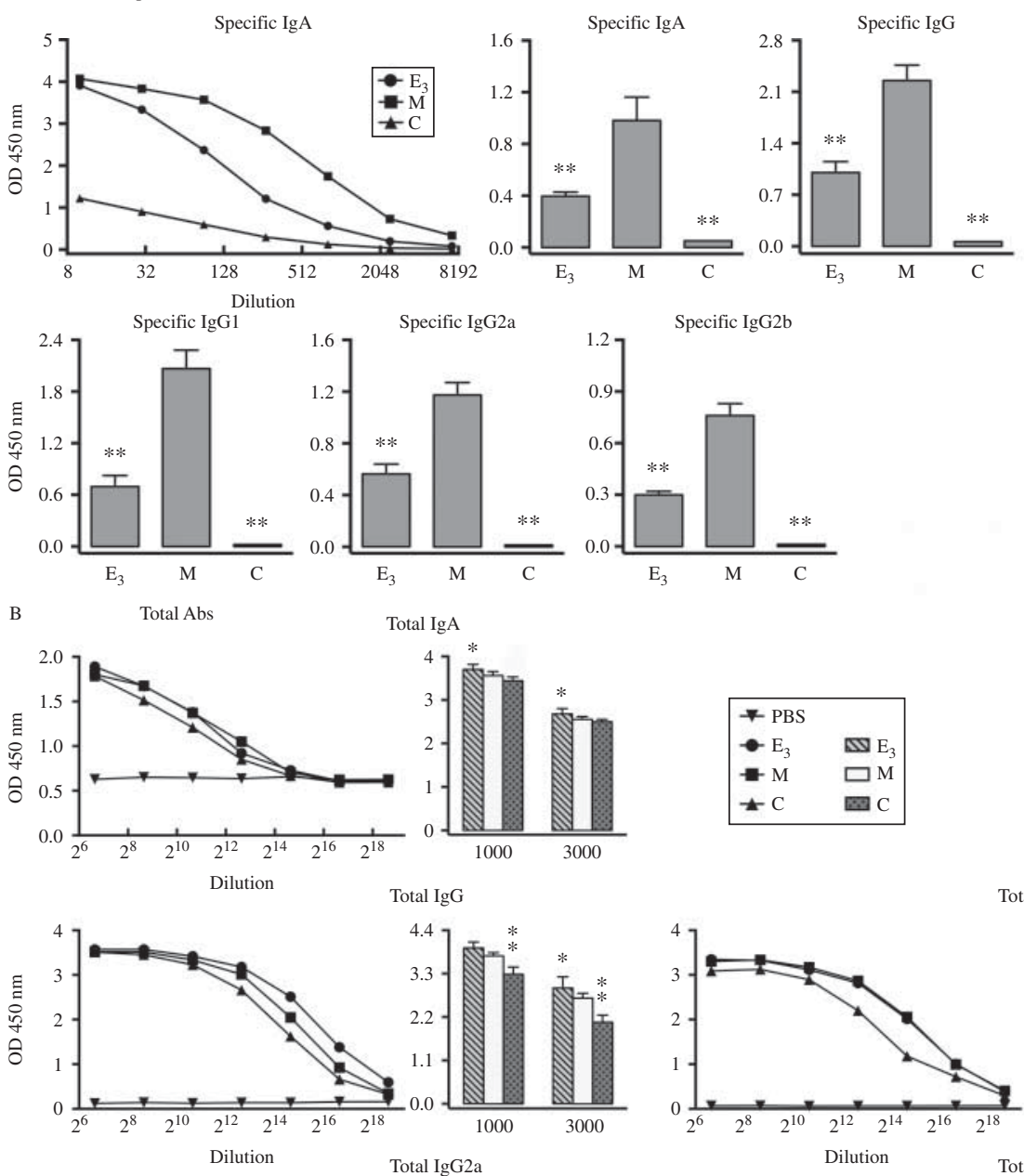

Total IgG1
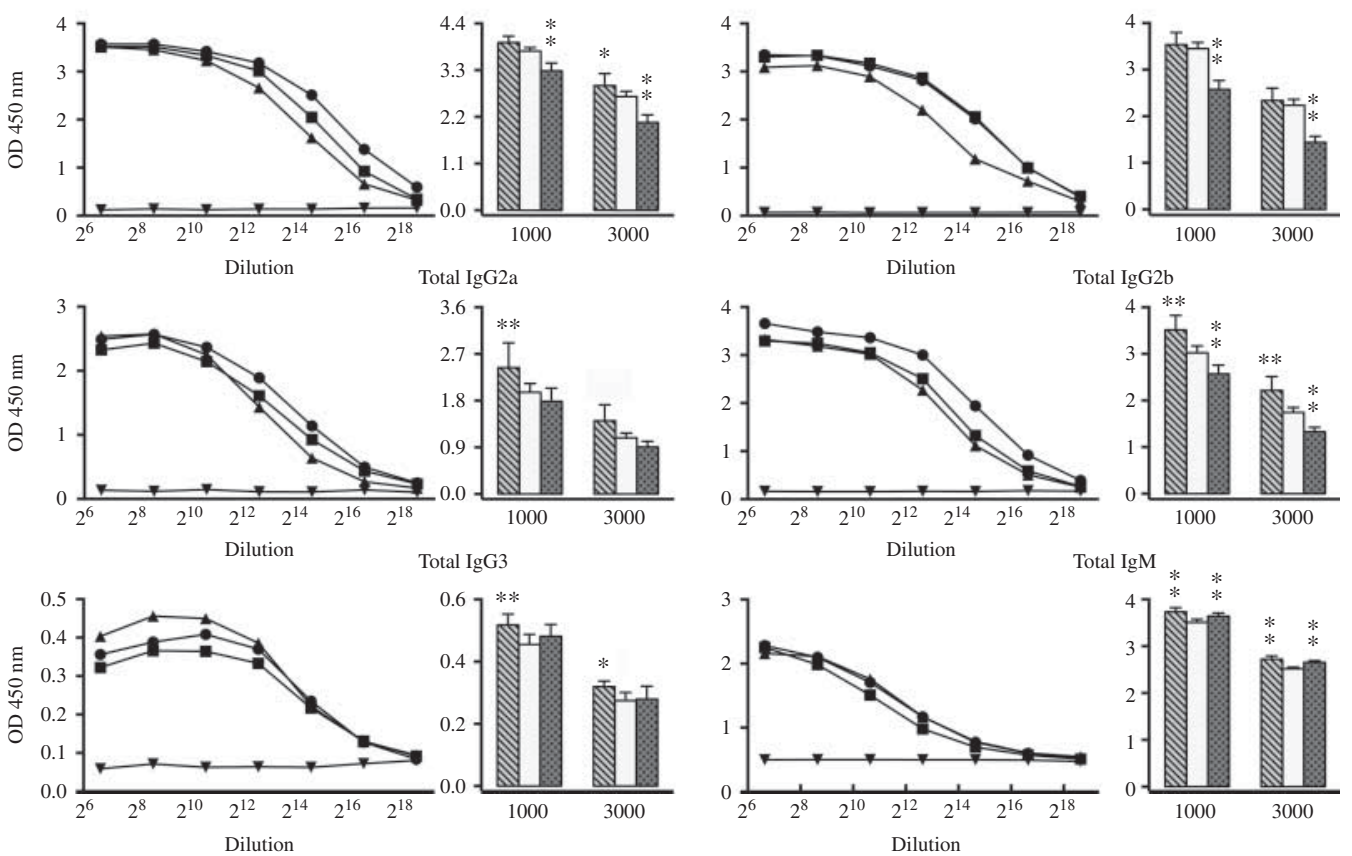

\section{Figure 3}

Administration of $E_{3}$ strongly suppresses DNCB-specific Abs in the sera of mice with DNCB-induced dermatitis. (A) Serum levels of DNCB-specific Abs on day 18 following DNCB treatment. Top left panel: serial dilution (1:10, $30,90,270,810,2430$, and 7290 ) of DNCB-specific IgA. The average value from two mice in each group was shown. Top middle, right, and bottom panels: mean \pm s.D. showing serum levels of DNCB-specific $\lg A, \lg G, \lg G 1$, IgG2a, and IgG2b at 1:600 dilution. $n=6$ for each group $* P<0.05$; $\star \star P<0.01$ vs the group of mice treated with DNCB alone ' $M$ '. (B) Serum levels of total Abs on day 18 following DNCB treatment. Line plots: average value of sera from two mice in each group showing the serial dilution $(1: 100,400,1600,6400,25600,102400$, and 409600$)$ of total IgA, IgG, $\lg G 1, \lg G 2 a, \lg G 2 b, \lg G 3$, and $\lg M$. PBS was also diluted with assay buffer as negative control. Bar plots: mean \pm s.D. showing serum levels of total IgA, $\lg$, IgG1, IgG2a, IgG2b, IgG3, and IgM at the dilution of 1:1000 and 1:3000. Referred in Fig. 1 for the meaning of the group labels. $n=6$ for each group ${ }^{*} P<0.05 ;{ }^{*} P<0.01$ vs the group of mice treated with DNCB alone ' $\mathrm{M}$ '.

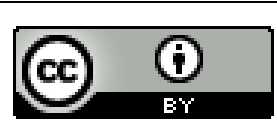


A

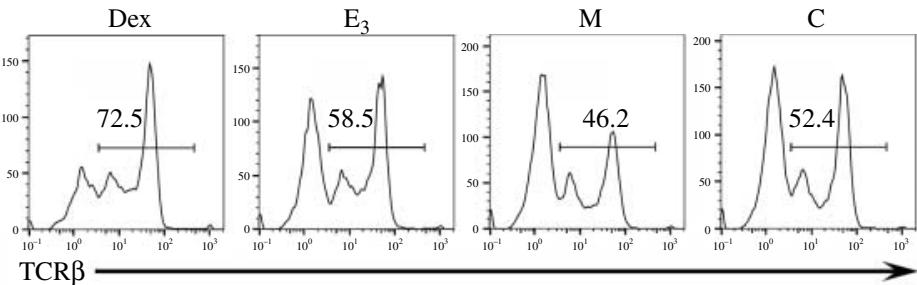

B

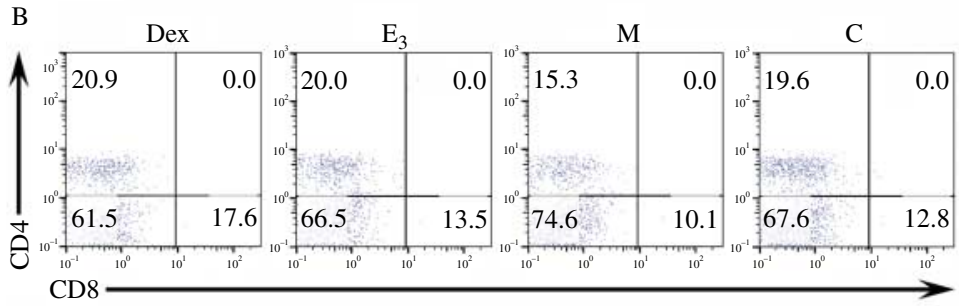$$
\mathrm{C}
$$

C

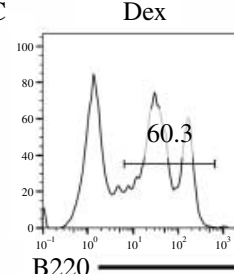

$\mathrm{E}_{3}$

M
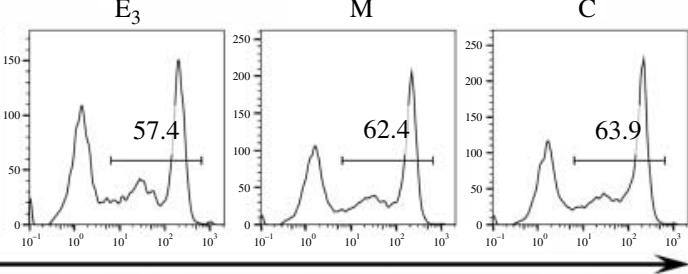

D

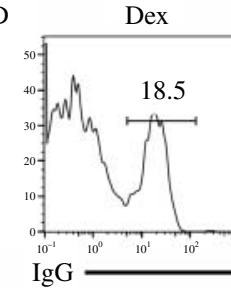

$\mathrm{E}_{3}$
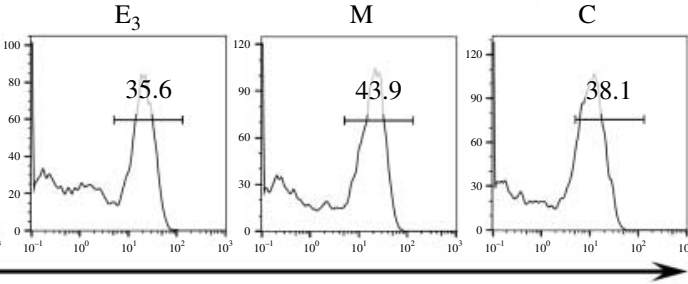

E

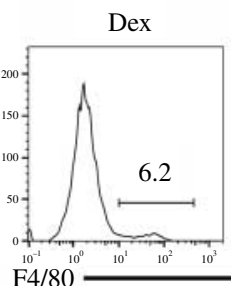

$\mathrm{E}_{3}$
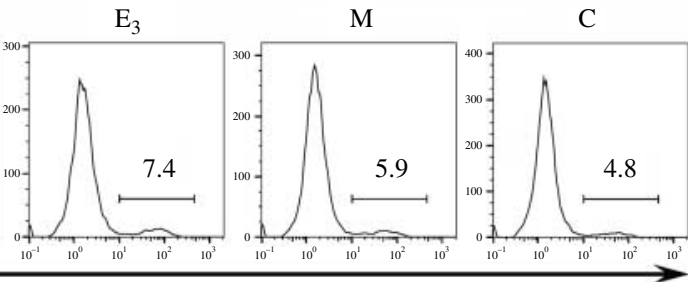

$\mathrm{F}$

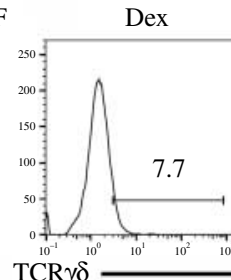

$\mathrm{E}_{3}$

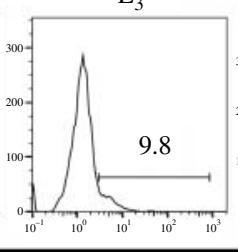

C

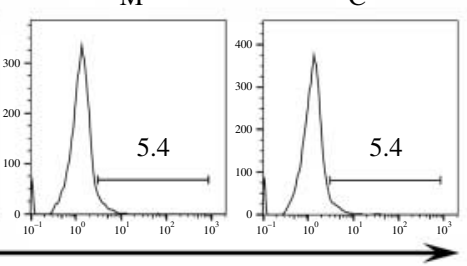

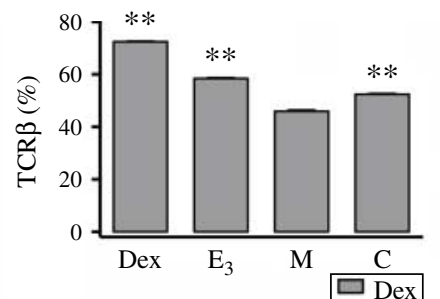

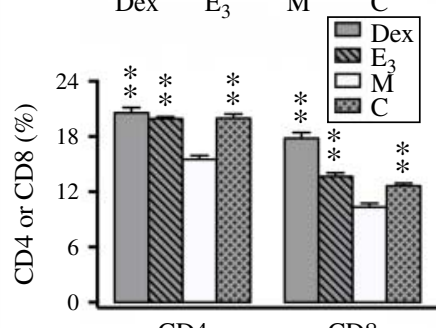

CD4

CD8
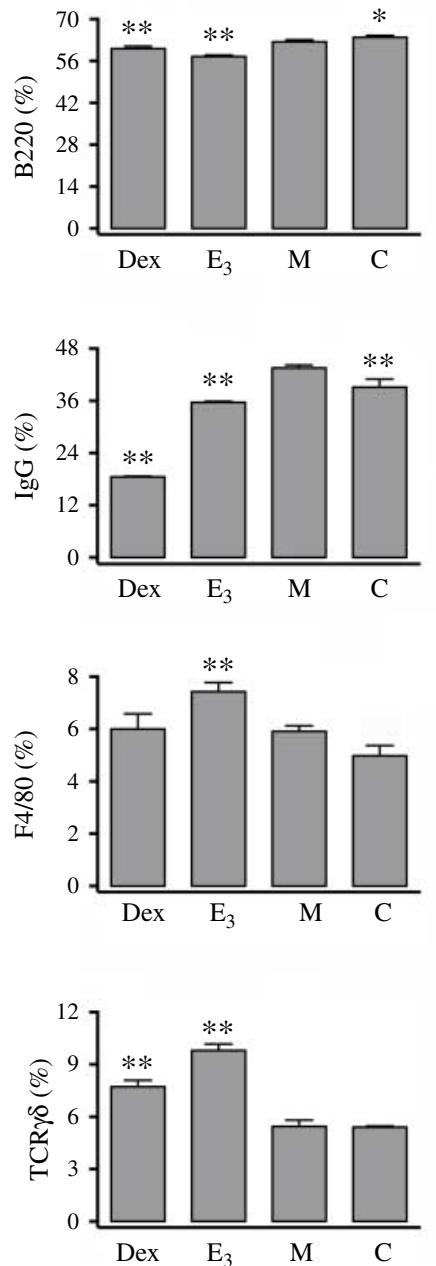

\section{Figure 4}

Effect of $E_{3}$ treatment on the lymphocyte composition in spleen.

Splenocytes from mice with DNCB-induced dermatitis or control mice were stained with various fluorochrome-conjugated antibodies and assayed for different cell surface markers. Left panels: representative histograms or dot plots. Right panels: summarized bar plots. $n=3$ for each group. ${ }^{*} P<0.05$; ${ }^{*} P<0.01$ vs the group of mice treated with DNCB alone ' $M$ '. Refer to Fig. 1 Published by Bioscientifica Ltd for the meaning of the group labels. In addition, mice labeled as group 'Dex' received Dex + DNCB. (A) Percentages of splenocytes expressing TCR $\beta$. (B) Percentages of splenocytes expressing CD4 or CD8. (C) Percentages of splenocytes expressing B220. (D) Percentages of splenocytes expressing IgG. (E) Percentages of splenocytes expressing F4/80. (F) Percentages of splenocytes expressing TCR $\gamma \delta$.

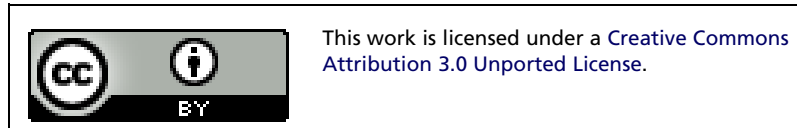


A
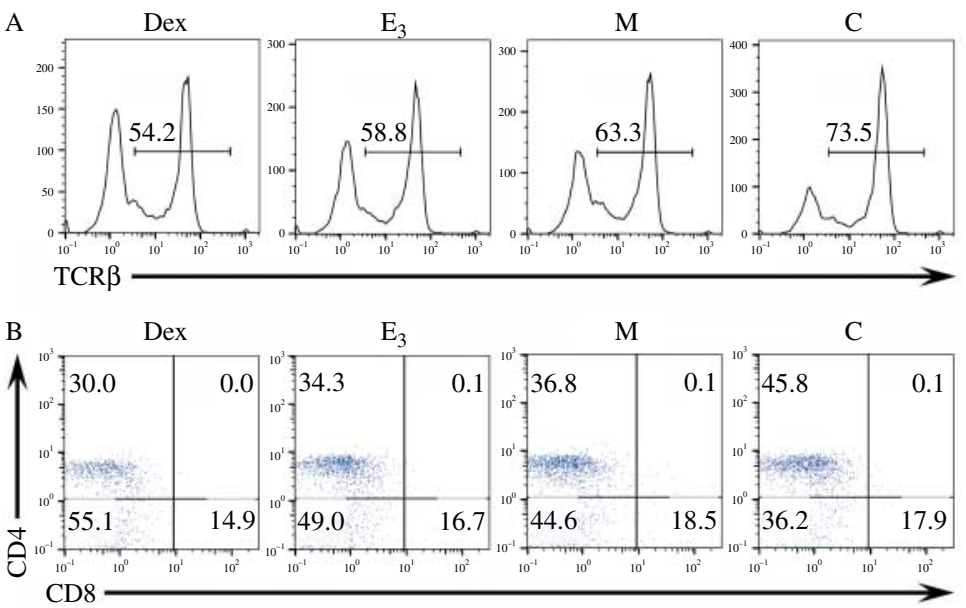

C
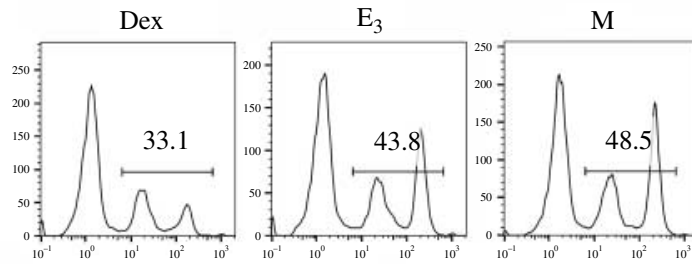

M

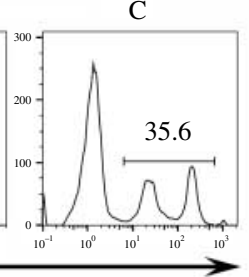

B220

D
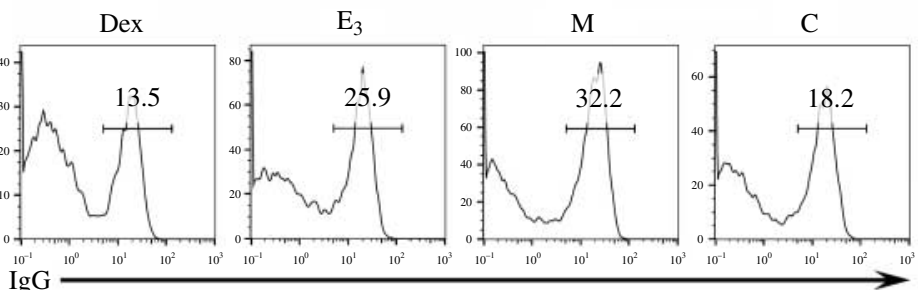

E

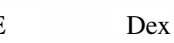

Dex
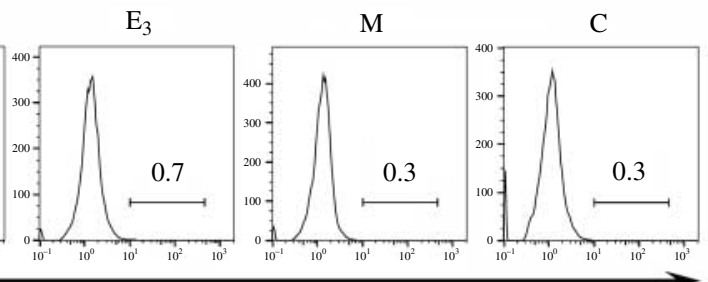

F4/80

F

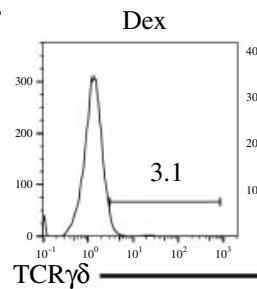

$\mathrm{E}_{3}$
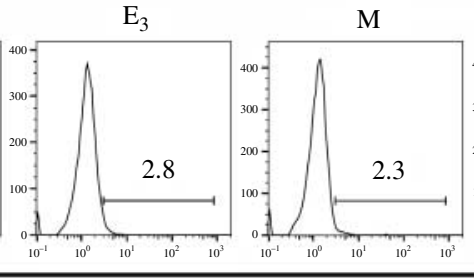

C

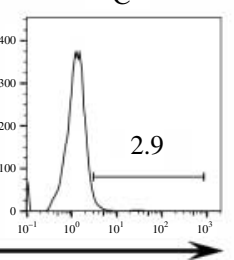

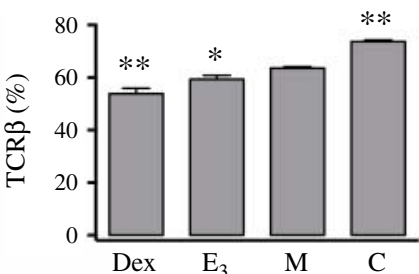
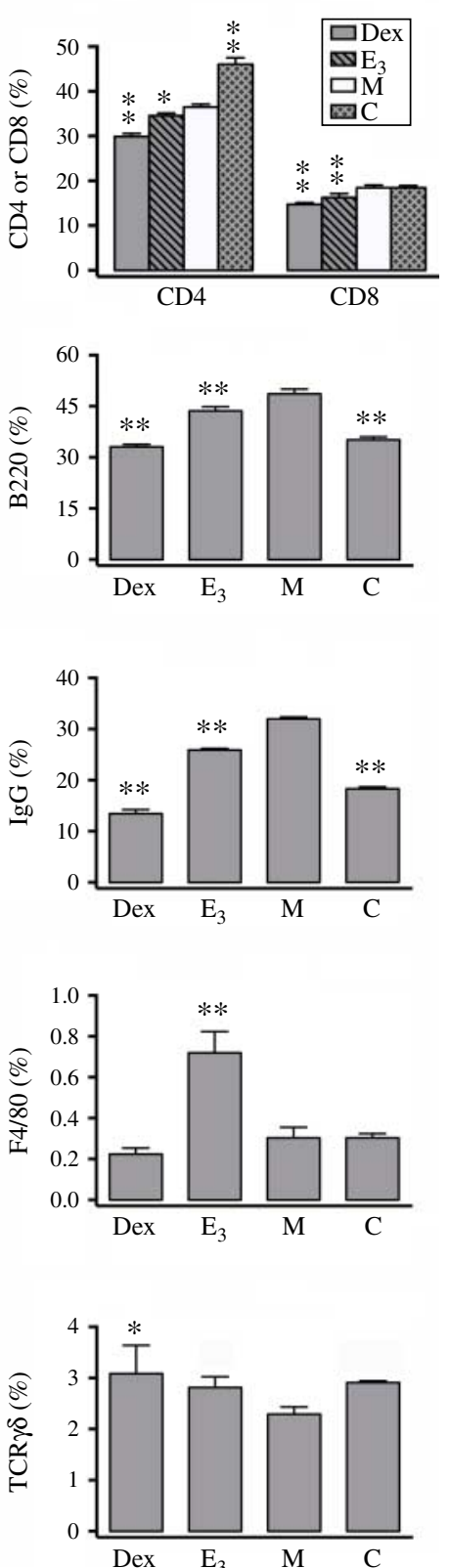

\section{Figure 5}

Effect of $E_{3}$ treatment on the lymphocyte composition in lymph nodes. Cells of peripheral lymph nodes from mice with DNCB-induced dermatitis or control mice were stained with various fluorochrome-conjugated antibodies and assayed for different cell surface markers. Left panels: representative histograms or dot plots. Right panels: summarized bar plot. $n=3$ for each group. ${ }^{*} P<0.05 ; * * P<0.01$ vs the group of mice treated with

http://www.endocrineconnections.org DOI: 10.1530/EC-14-0080 (c) 2014 The authors Published by Bioscientifica Ltd
DNCB alone ' $M$ '. Refer to Fig. 4 for the meaning of the group labels. (A) Percentages of lymph node cells expressing TCR $\beta$. (B) Percentages of lymph node cells expressing CD4 or CD8. (C) Percentages of lymph node cells expressing B220. (D) Percentages of lymph node cells expressing lgG. (E) Percentages of lymph node cells expressing F4/80. (F) Percentages of lymph node cells expressing $\mathrm{TCR} \gamma \delta$.

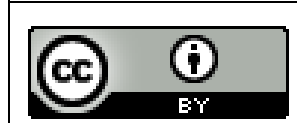

This work is licensed under a Creative Commons Attribution 3.0 Unported License. 
contact dermatitis by reducing inflammatory reactions. It has been reported that estrogen can regulate humoral immunity by modulating B cell development and function, such as Ab production (24). This information is in line with the notion that $\mathrm{E}_{3}$ may inhibit $\mathrm{CHS}$ via reduction of B cell composition and function, and ultimately, the production of antigen-specific Abs.

It is of interest to note that we found in this study that $E_{3}$ has a stronger therapeutic effect than $E_{2}$ (a far potent and efficacious endogenous estrogen) in an antigeninduced contact dermatitis model. Similar observations with $\mathrm{E}_{3}$ have also been reported earlier by us and others. For instance, it has been shown that $\mathrm{E}_{3}$ given at doses that can reach blood levels commonly seen during late stages of human pregnancy can produce a longer effect in delaying EAE onset than did $\mathrm{E}_{2}$ (3). Our recent studies $(21,25)$ have also shown that $E_{3}$ has rather distinct functions from $\mathrm{E}_{2}$ in the regulation of certain immune system functions, including the production of antigenspecific Abs and some splenocyte functions.

One of the possible explanations for the different effects of the three endogenous estrogens tested in this study may depend on their differential binding affinities for the estrogen receptors (ERs). $\mathrm{E}_{2}$ has high and similar binding affinity for both ER $\alpha$ (ESR1) and $\operatorname{Er} \beta$ (ESR2), and its binding affinities for both ERs are significantly higher than those of $E_{3}$ and $E_{1}(26)$. However, $E_{1}$ has a preferential binding affinity for $\mathrm{ER} \alpha$ over $\mathrm{ER} \beta$, and $\mathrm{E}_{3}$ has a preferential binding affinity for ER $\beta$ over ER $\alpha$ (26). ER $\alpha$ and ER $\beta$ are expressed in immune cells of both human and mice $(27,28)$, and thus it is possible that estrogens may have a direct effect on the immune system. This hypothesis is supported by some of the earlier studies. For instance, it was reported that $\mathrm{E}_{2}$ can directly act on $\mathrm{CD} 4^{+} / \mathrm{CD} 25^{-} \mathrm{T}$ cells via ER (29), which then directly interacts with $\mathrm{NF} \kappa \mathrm{B}$ to regulate the production of inflammatory cytokines $(30,31)$. However, it is also possible that estrogen may first act on other types of cells rather than lymphocytes to alter the production of regulatory factors and/or the activation of other cell types, which then further act on the immune system to modulate its functions. This possibility cannot be ruled out at present.

As mentioned earlier, $\mathrm{E}_{3}$ is a rather unique hormone in humans, and it is predominantly produced in large quantity during late pregnancy $(19,20)$. It has been reported that during human pregnancy, the circulating levels of total $\mathrm{E}_{3}$ drastically increased from the base levels (usually below $50 \mathrm{nM}$ ) to nearly $700 \mathrm{nM}$ at the late stages (32). In our studies, 4-5 days after pellet implantation, at which time the toxicity of estrogen treatment based on body weight change reaches peak level, the average plasma levels of free $E_{3}$ were found to be at $12.5 \mathrm{nM}$ (21), a level that is within the physiological range. As the body weight loss reaching maximum (12\%) at 4-5 days after estrogen pellet implantation, it quickly returned close to control level, suggesting that the animals recovered from the initial adverse effect of estrogen treatment. Like estrogen, treatment of Dex, which is a common therapeutic agent for contact dermatitis, also causes some weight loss $(33,34)$. Therefore, the observed levels of transient body weight change following estrogen treatment may be viewed as an acceptable adverse effect. In this study, it should also be mentioned that the pellets used in this study are of a sustained release type, which lasts for several months after implantation (35) and thereby provides a good method of administering estrogens for studying their effect on DNCB-induced CHS.

In the literature, there is actually no report concerning a role of pregnancy hormones in allergic contact dermatitis. Nevertheless, relevance between sex hormones and contact dermatitis can be deduced on the basis of some of the earlier studies. First, estrogens are known to promote skin elasticity and improve wound healing (36). Second, it was reported that skin response to allergens is markedly stronger at follicular phase than during ovulation $(37,38,39)$. Third, Bonamonte et al. reported that significantly fewer healthy women display intense responses to nickel-induced skin allergy during ovulation where endogenous estrogen levels are very high compared with luteal phase $(17,40)$. Lastly, some studies have suggested that ovulatory hormonal factors may act to suppress DTH reactions $(17,41,42)$. The findings of our present preclinical study, which demonstrate that administration of estrogens can strongly suppress the pathogenesis of allergic contact dermatitis, provide a good mechanistic explanation for these intriguing earlier clinical observations. In addition, these findings may offer a useful strategy for effectively alleviating the clinical symptoms of allergic human contact dermatitis.

\section{Declaration of interest}

The authors declare that there is no conflict of interest that could be perceived as prejudicing the impartiality of the research reported.

\section{Funding}

This study was supported, in part, by a grant from the NIH (RO1ES015242). Part of the work was done at the University of South Carolina (Columbia, SC 29208, USA) when the authors worked there.
This work is licensed under a Creative Commons Attribution 3.0 Unported License. 


\section{References}

1 Kovacs EJ, Messingham KA \& Gregory MS. Estrogen regulation of immune responses after injury. Molecular and Cellular Endocrinology 2002193 129-135. (doi:10.1016/S0303-7207(02)00106-5)

2 Bebo BF Jr, Fyfe-Johnson A, Adlard K, Beam AG, Vandenbark AA \& Offner H. Low-dose estrogen therapy ameliorates experimental autoimmune encephalomyelitis in two different inbred mouse strains. Journal of Immunology 2001166 2080-2089. (doi:10.4049/jimmunol. 166.3.2080)

3 Jansson L, Olsson T \& Holmdahl R. Estrogen induces a potent suppression of experimental autoimmune encephalomyelitis and collagen-induced arthritis in mice. Journal of Neuroimmunology 199453 203-207. (doi:10.1016/0165-5728(94)90030-2)

4 Ito A, Bebo BF Jr, Matejuk A, Zamora A, Silverman M, Fyfe-Johnson A \& Offner H. Estrogen treatment down-regulates TNF- $\alpha$ production and reduces the severity of experimental autoimmune encephalomyelitis in cytokine knockout mice. Journal of Immunology 2001167 542-552. (doi:10.4049/jimmunol.167.1.542)

5 Josefsson E, Tarkowski A \& Carlsten H. Anti-inflammatory properties of estrogen. I. In vivo suppression of leukocyte production in bone marrow and redistribution of peripheral blood neutrophils. Cellular Immunology 1992142 67-78. (doi:10.1016/0008-8749(92)90269-U)

6 Harnish DC, Albert LM, Leathurby Y, Eckert AM, Ciarletta A, Kasaian M \& Keith JC Jr. Beneficial effects of estrogen treatment in the HLA-B27 transgenic rat model of inflammatory bowel disease. American Journal of Physiology. Gastrointestinal and Liver Physiology 2004286 G118-G125. (doi:10.1152/ajpgi.00024.2003)

7 Asherson GL \& Ptak W. Contact and delayed hypersensitivity in the mouse. I. Active sensitization and passive transfer. Immunology 196815 405-416.

8 Wang B, Feliciani C, Freed I, Cai Q \& Sauder DN. Insights into molecular mechanisms of contact hypersensitivity gained from gene knockout studies. Journal of Leukocyte Biology 200170 185-191.

9 Askenase PW. Yes T cells, but three different T cells (alphabeta, gammadelta and NK T cells), and also B-1 cells mediate contact sensitivity. Clinical and Experimental Immunology 2001125 345-350. (doi:10.1046/j.1365-2249.2001.01619.x)

10 Kehren J, Desvignes C, Krasteva M, Ducluzeau MT, Assossou O, Horand F, Hahne M, Kagi D, Kaiserlian D \& Nicolas JF. Cytotoxicity is mandatory for CD8(+) T cell-mediated contact hypersensitivity. Journal of Experimental Medicine 1999189 779-786. (doi:10.1084/jem.189.5.779)

11 Tuckermann JP, Kleiman A, Moriggl R, Spanbroek R, Neumann A, Illing A, Clausen BE, Stride B, Forster I, Habenicht AJ et al. Macrophages and neutrophils are the targets for immune suppression by glucocorticoids in contact allergy. Journal of Clinical Investigation $2007 \mathbf{1 1 7}$ 1381-1390. (doi:10.1172/JCI28034)

12 Wang B, Fujisawa H, Zhuang L, Freed I, Howell BG, Shahid S, Shivji GM, Mak TW \& Sauder DN. CD4 + Th1 and CD8 + type 1 cytotoxic $\mathrm{T}$ cells both play a crucial role in the full development of contact hypersensitivity. Journal of Immunology 2000165 6783-6790. (doi:10.4049/jimmunol.165.12.6783)

13 Watanabe R, Fujimoto M, Ishiura N, Kuwano Y, Nakashima H, Yazawa N, Okochi H, Sato S, Tedder TF \& Tamaki K. CD19 expression in B cells is important for suppression of contact hypersensitivity. American Journal of Pathology 2007 171 560-570. (doi:10.2353/ajpath.2007.061279)

14 Campos RA, Szczepanik M, Itakura A, Lisbonne M, Dey N, Leite-de-Moraes MC \& Askenase PW. Interleukin-4-dependent innate collaboration between iNKT cells and B-1 B cells controls adaptative contact sensitivity. Immunology 2006117 536-547. (doi:10.1111/ j.1365-2567.2006.02330.x)

15 O'Leary JG, Goodarzi M, Drayton DL \& von Andrian UH. T cell- and B cell-independent adaptive immunity mediated by natural killer cells. Nature Immunology 20067 507-516. (doi:10.1038/ni1332)
16 Zhang EY, Chen AY \& Zhu BT. Mechanism of dinitrochlorobenzeneinduced dermatitis in mice: role of specific antibodies in pathogenesis. PLoS ONE 20094 e7703. (doi:10.1371/journal.pone.0007703)

17 Bonamonte D, Foti C, Antelmi AR, Biscozzi AM, Naro ED, Fanelli M, Loverro G \& Angelini G. Nickel contact allergy and menstrual cycle. Contact Dermatitis 200552 309-313. (doi:10.1111/j.0105-1873.2005.00588.x)

18 Ezaki T, Nawa Y, Hayama T, Yamaguchi K \& Kotani M. Modulation of the immune responses against SRBC after oestriol treatment in mice. Clinical and Experimental Immunology 198248 239-243.

19 Merrill RC. Estriol: a review. Physiological Reviews 195838 463-480.

20 Fotsis T. The multicomponent analysis of estrogens in urine by ion exchange chromatography and GC-MS - II. Fractionation and quantitation of the main groups of estrogen conjugates. Journal of Steroid Biochemistry 198728 215-226. (doi:10.1016/0022-4731(87)90380-3)

21 Zhou R, Lai Y, Yamabe N, Fukui M \& Zhu BT. Estriol has different effects from $17 \beta$-estradiol in modulating mouse splenocyte function under inflammatory conditions. Journal of Immunotoxicology 20118 346-358. (doi:10.3109/1547691X.2011.617791)

22 Leung DY, Boguniewicz M, Howell MD, Nomura I \& Hamid QA. New insights into atopic dermatitis. Journal of Clinical Investigation 2004113 651-657. (doi:10.1172/JCI21060)

23 Haldar C, Rai S \& Singh R. Melatonin blocks dexamethasone-induced immunosuppression in a seasonally breeding rodent Indian palm squirrel, Funambulus pennanti. Steroids 200469 367-377. (doi:10.1016/ j.steroids.2004.03.006)

24 Sakiani S, Olsen NJ \& Kovacs WJ. Gonadal steroids and humoral immunity. Nature Reviews. Endocrinology 20139 56-62. (doi:10.1038/ nrendo.2012.206)

25 Ding J \& Zhu BT. Unique effect of the pregnancy hormone estriol on antigen-induced production of specific antibodies in female BALB/c mice. Steroids 200873 289-298. (doi:10.1016/j.steroids.2007. 10.012)

26 Zhu BT, Han GZ, Shim JY, Wen Y \& Jiang XR. Quantitative structureactivity relationship of various endogenous estrogen metabolites for human estrogen receptor $\alpha$ and $\beta$ subtypes: insights into the structural determinants favoring a differential subtype binding. Endocrinology 2006147 4132-4150. (doi:10.1210/en.2006-0113)

27 Pierdominici M, Maselli A, Colasanti T, Giammarioli AM, Delunardo F, Vacirca D, Sanchez M, Giovannetti A, Malorni W \& Ortona E. Estrogen receptor profiles in human peripheral blood lymphocytes. Immunology Letters 2010132 79-85. (doi:10.1016/j.imlet.2010.06.003)

28 Tornwall J, Carey AB, Fox RI \& Fox HS. Estrogen in autoimmunity: expression of estrogen receptors in thymic and autoimmune T cells. Journal of Gender-Specific Medicine 19992 33-40.

29 Tai P, Wang J, Jin H, Song X, Yan J, Kang Y, Zhao L, An X, Du X, Chen X et al. Induction of regulatory $\mathrm{T}$ cells by physiological level estrogen. Journal of Cellular Physiology 2008214 456-464. (doi:10.1002/jcp. 21221)

30 McKay LI \& Cidlowski JA. Molecular control of immune/inflammatory responses: interactions between nuclear factor- $\mathrm{B}$ and steroid receptorsignaling pathways. Endocrine Reviews 199920 435-459.

31 Ray P, Ghosh SK, Zhang DH \& Ray A. Repression of interleukin-6 gene expression by $17 \beta$-estradiol: inhibition of the DNA-binding activity of the transcription factors NF-IL6 and NF- $\kappa \mathrm{B}$ by the estrogen receptor. FEBS Letters 1997409 79-85. (doi:10.1016/S0014-5793(97)00487-0)

32 Kaijser M, Granath F, Jacobsen G, Cnattingius S \& Ekbom A. Maternal pregnancy estriol levels in relation to anamnestic and fetal anthropometric data. Epidemiology 200011 315-319. (doi:10.1097/00001648200005000-00015)

33 Nakayama N, Yamaura K, Shimada M \& Ueno K. Extract from peel of Citrus natsudaidai alleviates experimental chronic allergic dermatitis in mice. Pharmacological Research 20113 155-159. (doi:10.4103/09748490.84999)

34 Shih A \& Jackson KC II. Role of corticosteroids in palliative care. Journal of Pain \& Palliative Care Pharmacotherapy 200721 69-76. (doi:10.1080/J354v21n04_14)

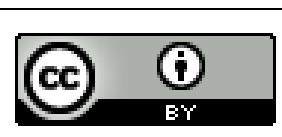

This work is licensed under a Creative Commons Attribution 3.0 Unported License. 
35 Mills LH, Yu J, Xu XM, Lee AJ \& Zhu BT. Naturally-occurring estradiol$17 \beta$-fatty acid esters, but not estradiol-17 $\beta$, preferentially induce mammary tumorigenesis in female rats: implications for an important role in human breast cancer. Toxicology and Applied Pharmacology 2008 229 332-341. (doi:10.1016/j.taap.2008.01.042)

36 Shah MG \& Maibach HI. Estrogen and skin. An overview. American Journal of Clinical Dermatology 20012 143-150. (doi:10.2165/00128071200102030-00003)

37 Farage MA, Berardesca E \& Maibach $\mathrm{H}$. The possible relevance of sex hormones on irritant and allergic responses: their importance for skin testing. Contact Dermatitis 201062 67-74. (doi:10.1111/j.16000536.2009.01621.x)

38 Agner T, Damm P \& Skouby SO. Menstrual cycle and skin reactivity. Journal of the American Academy of Dermatology 199124 566-570. (doi:10.1016/0190-9622(91)70084-F)
39 Agner T. Noninvasive measuring methods for the investigation of irritant patch test reactions. A study of patients with hand eczema, atopic dermatitis and controls. Acta Dermato-Venereologica. Supplementum 1992173 1-26.

40 Cortes-Gallegos V, Gallegos AJ, Tovar NB, Cervantes C \& Parra A. Effect of paramethasone acetate on ovarian steroids and gonadotropins. I. Normal menstrual cycle. Journal of Clinical Endocrinology and Metabolism 197541 215-220. (doi:10.1210/jcem-41-2-215)

41 Hindsen M, Bruze M \& Christensen OB. Individual variation in nickel patch test reactivity. American Journal of Contact Dermatitis 199910 62-67. (doi:10.1016/S1046-199X(99)90001-5)

42 Tamer E, Ikizoglu G, Toy GG \& Alli N. Comparison of nickel patch test reactivity in phases of the menstrual cycle. International Journal of Dermatology 200342 455-458. (doi:10.1046/j.1365-4362.2003. 01708.x)

Received in final form 6 August 2014

Accepted 22 August 2014
This work is licensed under a Creative Commons Attribution 3.0 Unported License. 